\section{Foliar Sprays of Clay Reduce the Severity of Powdery Mildew on Long English Cucumber and Wine Grapes}

\author{
David L. Ehret ${ }^{1}$ and Carol Koch \\ Pacific Agri-Food Research Centre, Agriculture and Agri-Food Canada, P.O. \\ Box 1000, Agassiz, BC VOM 1A0, Canada
}

Jim Menzies

Cereal Research Centre, Agriculture and Agri-Food Canada, 195 Dafoe Road, Winnipeg, MB R3T 2M9, Canada

Peter Sholberg

Pacific Agri-Food Research Centre, Agriculture and Agri-Food Canada, Highway 97, Summerland, BC VOH 1Z0, Canada

Tim Garland

Inland Machinery Manufacturing, 205, 20381-62 Avenue, Langley, BC V3A 5E6, Canada

Additional index words. Cucumis sativus, Sphaerotheca fuliginea, surfactants, Uncinula necator, Vitis vinifera

Abstract. Foliar sprays of a nonswelling chlorite mica clay were applied to leaves of greenhouse-grown long English cucumber (Cucumis sativus L.) plants, either before or after an artificial inoculation with powdery mildew [Sphaerotheca fuliginea (Schlech.:Fr.) Poll.] and to field-grown wine grapes (Vitis vinifera L.) before natural inoculation with powdery mildew [Uncinula necator (Schwein.) Burrill]. In all cases, the clay sprays did not eradicate the pathogen, but resulted in significant reductions in disease severity. In cucumber, a single spray of $0.5 \%$ clay reduced colony numbers on leaves by up to $60 \%$. Spraying after inoculation was generally more effective than spraying before inoculation. In grapes, repeated sprays of either $2 \%$ or $4 \%$ clay were applied through the season to 'Reisling' and 'Chancellor' vines. Four percent clay reduced the amount of leaf surface covered by mildew by $22 \%$ in 'Reisling' and $51 \%$ in 'Chancellor'. Both concentrations reduced the incidence of mildew on clusters and canes. No treatment effects were observed on fruit quality. Our results demonstrate that foliar sprays of clay can reduce the severity of Sphaerotheca fuliginea and Uncinula necator on cucumbers and grapes, respectively.

Powdery mildew fungi are arguably the most common and destructive pathogens of greenhouse crops and wine grapes. These fungi can develop rapidly in favorable greenhouse environments and outside in warm summer climates, causing considerable economic damage to crops such as cucumber and grape. In Canada, the main powdery mildew pathogen of greenhouse-grown long English cucumber plants is Sphaerotheca fuliginea and of grapes is Uncinula necator. Recommended control practices include the growing of resistant varieties and application of fungicides (British

Received for publication 21 Sept. 2000. Accepted for publication 20 Mar. 2001. Pacific Agri-Food Research Centre Contribution No. 635. We wish to acknowledge the financial assistance of the Ironwood Clay Co. Inc. and the Matching Investment Initiative of Agriculture and Agri-Food Canada. Use of trade names does not imply endorsement of the products named nor criticism of similar ones not named. The cost of publishing this paper was defrayed in part by the payment of page charges. Under postal regulations, this paper therefore must be hereby marked advertisement solely to indicate this fact.

${ }^{1}$ To whom reprint requests should be addressed. E-mail address: ehretd@em.agr.ca
Columbia Ministry of Agriculture, Fisheries and Food, 1996), but these practices do not always lead to satisfactory results.

Resistant cultivars of long English cucumber are available to growers, but are often not used because of leaf yellowing and necrosis under low light intensity (British Columbia Ministry of Agriculture, Fisheries and Food, 1996), and their having lower yields than nonresistant cultivars. The three fungicides currently registered for powdery mildew control on greenhouse cucumber in Canada (elemental sulfur, a benomyl-manzate mixture, and dinocap) also have their limitations: formulated elemental sulfur can cause severe leaf damage after repeated applications; benomylmanzate is harmful to insect biocontrol agents, and many powdery mildew isolates are now likely to be resistant; and dinocap has a preharvest interval of $30 \mathrm{~d}$.

Grapes used in the production of wine are usually Vitis vinifera types because they produce the most desirable wines. Vitis vinifera species are highly susceptible to powdery mildew pathogens, while American species such as $V$. aestivalis, $V$. berlandieri, $V$. cinerea, $V$. riparia, and $V$. rupestris, although not com- mercially grown for wine, are much less susceptible (Pearson, 1988). In Canada, control of powdery mildew on grapes relies heavily on use of myclobutanil (Nova) for prebloom and bloom applications, followed by sulfur cover sprays throughout the growing season. However, sulfur can cause severe burns on vines if applied when air temperatures are near $38^{\circ} \mathrm{C}$ (Sall et al., 1981), and wineries usually require that sulfur not be used within $30 \mathrm{~d}$ of harvest for fear of its effect on wine quality. Resistance to myclobutanil may also develop in $U$. necator populations (Ypema et al., 1997).

The importance of powdery mildew on cucumber and grapes has, over the years, led to experimentation with some novel and interesting control techniques. The majority of this work was aimed at developing powdery mildew control techniques that were effective, low cost, readily available, easy to apply, compatible with crop management practices, and acceptable to regulatory agencies and the general public. The substances used include plant and compost extracts, various salts, oils, antitranspirants, and detergents. An overview of this area of research was recently provided by Bélanger et al. (1998).

Marco et al. (1994) examined the effectiveness of foliar sprays of whitewash, clay, and antitranspirants on the incidence of $S$. fuliginea on squash (Cucurbita pepo L.). Weekly sprays with whitewash or clay suppressed the incidence of the pathogen on squash plants in the field by $50 \%$ to $60 \%$. This led us to consider experimenting with clay as a potential control agent for powdery mildew of cucumber and wine grapes. Preliminary reports of successful trials conducted with grapes have previously been reported (Sholberg and Lashuk, 1998, 1999). The objective of our experiments was to determine the effectiveness of foliar dusts or sprays of clay in reducing the severity of powdery mildews on cucumber and grape.

\section{Materials and Methods}

\section{Greenhouse Experiments on Cucumbers}

All cucumber experiments were conducted at the Pacific Agri-Food Research Centre, Agassiz, B.C. Seeds of long English cucumber cv. Corona (DeRuiter Seeds, Columbus, Ohio) were sown into rockwool cubes on greenhouse benches and fertilized with a standard hydroponic nutrient solution (British Columbia Ministry of Agriculture, Fisheries and Food, 1996). Foliar clay treatments were applied when the cucumber plants had four fully expanded leaves. The clay used in all trials was a nonswelling chlorite mica clay (Minerall ${ }^{\mathrm{TM}}$ Clay, Ironwood Clay Co., Richmond, B.C.). Physical characteristics of the clay have been reported by Ehret et al. (1998).

Conidia of $S$. fuliginea were collected from naturally infected leaves of cucumber. Source leaves were shaken $24 \mathrm{~h}$ before harvest of the conidia to dislodge old conidia. The conidia were inoculated onto the adaxial surface of the leaves of plants in an undiluted Fluorinert suspension (3M Speciality Chemical Divi- 
sion, St. Paul, Minn.; Menzies and MacNeill 1986, Reeser et al., 1983).

Claydusting. The initial experiment examined the effect of a foliar dust application of powdered clay on the number of colonies of powdery mildew that developed after inoculation with conidia of $S$. fuliginea. The treatments consisted of untreated control plants, plants dusted with the clay $2 \mathrm{~h}$ before pathogen inoculation, and plants dusted with clay $2 \mathrm{~h}$ after inoculation. The clay was applied with a commercial dusting apparatus normally used for applying sulfur for disease control in commercial greenhouses. There were 12 plants per treatment arranged in a completely randomized design on a greenhouse bench (plants were removed for the dusting treatment and then returned to the original greenhouse bench) Each third leaf was inoculated with $\approx 0.5 \mathrm{~mL}$ of a 2500 conidial $/ \mathrm{mL}$ suspension of $S$. fuliginea. Inoculated plants were incubated in the greenhouse for 7 to $10 \mathrm{~d}$, at which time powdery mildew colonies on the leaves were counted. The data were tested for homogeneity of variance, transformed to square root where appropriate, and analyzed using analysis of variance (ANOVA), followed by a Student-NewmanKeuls test for means separation. The experiment was performed twice.

Clay sprays. These experiments examined the effect of foliar sprays of clay on powdery mildew development. Water control sprays and $0.5 \%(\mathrm{w} / \mathrm{v})$ clay sprays were applied either $24 \mathrm{~h}$ before or $24 \mathrm{~h}$ after pathogen inoculation. There were 10 plants per treatment. All sprays contained $0.05 \%(\mathrm{v} / \mathrm{v})$ Tween 80 . Each third leaf was inoculated with $0.5 \mathrm{~mL}$ of a 4000 conidia/mL of $S$. fuliginea fluorinert suspension. Colony counts were made 7 to $10 \mathrm{~d}$ after inoculation. The data for each experiment was tested for homogeneity of variance and the means transformed to square root where appropriate and analyzed using contrasts. The experiment was performed three times.

Surfactant vs. clay. The roles of clay and Tween 80 were compared in these experiments. Water, water plus Tween $80(0.1 \%)$, and water plus Tween $80(0.1 \%)$ plus clay $(0.5 \% \mathrm{w} / \mathrm{v})$ sprays were applied either $24 \mathrm{~h}$ before or $24 \mathrm{~h}$ after pathogen inoculation, using 10 plants per treatment. The third leaf of each plant was inoculated with $0.5 \mathrm{~mL}$ of a 3000 conidia/mL of $S$. fuliginea fluorinert suspension. Colony counts were made 7 to 10 $\mathrm{d}$ after inoculation. The data were analyzed in the same manner as in the spray experiments. The experiment was performed three times.

\section{Vineyard Experiments on Wine Grapes}

The trials were conducted at the Pacific Agri-Food Research Centre, Summerland, B.C., in 1997 on 'Reisling' (Vitis vinifera L.) and in 1998 on 'Chancellor' (Vitis vinifera L.) grapevines. The mature, high cordon-trained vines at a $2.0 \times 2.5 \mathrm{~m}$ (within $\times$ between) row spacing were spur-pruned and hedged about the time of berry development. The experimental design was a randomized complete block with four treatments replicated four times for each cultivar. Each replicate consisted of five 'Reisling' or three 'Chancellor' vines with the end vine or half vine in the case of 'Chancellor' acting as barriers between treatments. Clay (Minerall ${ }^{\mathrm{TM}}$ Clay, Ironwood Clay Co.) treatments of (i) $2.0 \%$ and (ii) $4.0 \%$ (w/v; this equates to 20 or $40 \mathrm{~kg} \cdot \mathrm{ha}^{-1}$ clay for spray rates based on $1000 \mathrm{~L} \cdot \mathrm{ha}^{-1}$ of water), and (iii) myclobutanil (Nova $40 \mathrm{WP}$, Rohm \& Haas Canada, West Hill, Ont.) at $7.5 \mathrm{~g} \cdot \mathrm{L}^{-1}$ of water were applied using a handgun sprayer at a pressure of $3000 \mathrm{kPa}$ in order to thoroughly cover grape foliage, canes, and clusters. Plants were sprayed until runoff. Constant agitation was maintained to keep clay and myclobutanil in suspension during spraying. The control treatment was not sprayed. Incidence of powdery mildew was evaluated near harvest on 120 leaves, 15 internodes, and 10 grape clusters, selected at random, per replicate for each treatment (Sholberg and Lashuk, 1999). In each case, the percentage of surface covered by mildew was estimated visually.

One hundred-berry samples were taken from randomly selected clusters of each treatment (one sample per replicate) during the normal harvest to determine the effect of clay on juice quality. From each of these, 50-g subsamples were subjected to a nonvolatile acid extraction procedure, and titratable acidity was determined on the extracts using a Brinkmann Titroprocessor ensemble (Metrohm, Herisau, Switzerland). The rest of the sample was juiced, and soluble solids concentration ( ${ }^{\circ}$ Brix) and $\mathrm{pH}$ were measured on settled juice using an Abbé refractometer (AO Instruments, Buffalo, N.Y.) and pH meter, respectively. Effects on fermentation were not evaluated.

Percent incidence of leaf, cane, and cluster powdery mildew were arcsin-transformed and the berry weight per 100 berries, $\mathrm{pH}$, titratable acid, and soluble solids were subjected to ANOVA with the General Linear Models Procedure (SAS Institute, Cary, N.C.). The WallerDuncan $K$-ratio $t$ test $(\mathrm{K}=100)$ and the Duncan multiple range test $(P=0.05)$ were used to separate means of disease incidence.

'Reisling' experiment. Clay and myclobutanil treatments were applied to Johannesburg 'Reisling' wine grapes on 13 June (bloom), 27 June (postbloom), 16 July (berry touch), 31 July (preveraison), 21 Aug. (veraison), and 12 Sept. 1997 (postveraison). Powdery mildew was evaluated at harvest on 5 Nov. 1997.

'Chancellor' experiment. Clay and myclobutanil treatments were applied to 'Chancellor' wine grapes on 28 May (bloom), 11 June (berry touch), 24 Aug. (veraison), and 24 Sept. (postveraison) 1998. Powdery mildew was evaluated on 15 Oct.1998, 2 weeks after harvest.

\section{Results}

\section{Greenhouse Experiments on Cucumbers}

Clay dusting. Dusting the cucumber foliage with clay significantly $(P<0.01)$ reduced the number of colonies of $S$. fuliginea on the leaves in the first trial. The nondusted control leaves averaged 125 colonies per leaf, which was significantly more colonies per leaf than found on the leaves dusted with clay prior to ( 76 colonies) or after inoculation ( 44 colonies) with the pathogen. In the second trial, clay dusting before or after inoculation with the pathogen did not significantly affect pathogen colony numbers. The control treatment had 167 colonies per leaf and there were no significant $(P=0.2543)$ differences among the three treatments in the number of pathogen colonies (data not shown).

Clay sprays. Clay applied as $0.5 \%$ foliar sprays was effective in significantly $(P<$ $0.0001)$ reducing the number of colonies of $S$. fuliginea on the cucumber leaves in all three trials (Table 1). In general, the postinoculation sprays of the cucumber leaves resulted in lower colony numbers than the preinoculation sprays, but this was only significant $(P<$ 0.0001 ) in trial 2.

Surfactant vs. clay. In all three trials, postinoculation sprays resulted in significantly fewer colonies of $S$. fuliginea on the cucumber leaves compared with preinoculation sprays (Table 2). Similarly, sprays of $0.5 \%$ clay plus Tween 80 resulted in significantly fewer colonies than sprays of Tween 80 alone. Foliar sprays of $0.1 \%$ Tween 80 significantly reduced colony numbers in trials 1 and 3, but not in trial 2, compared with the water spray control.

\section{Vineyard Experiments on Wine Grapes}

'Reisling' experiment. Powdery mildew did not occur on 'Reisling' grape foliage until a few weeks before harvest and never occurred on the clusters. Clay at the rate of $4 \%$ was more effective than myclobutanil (Nova) in reducing powdery mildew on the leaves at this late date (Table 3). The treatments had no effect on cane mildew, with surface area covered ranging from $15 \%$ to $36 \%$. None of the treatments had any significant effect $(P>0.05)$ on grape juice quality $(\mathrm{pH}$ ranged from 3.02 to 3.16 ,

Table 1. Effect of foliar application of clay suspensions on the number of colonies of Sphaerotheca fuliginea forming on the leaves of cucumber plants.

\begin{tabular}{llll}
\hline \hline Foliar spray & Trial 1 & Trial 2 & Trial 3 \\
\hline Water & & & \\
$\quad$ Preinoculation & & & \\
Postinoculation $^{\mathrm{y}}$ & 98.9 & 256.7 & 403.6 \\
0.5\% Clay & & 170 & 377.3 \\
$\quad$ Preinoculation $^{\mathrm{y}}$ & 50 & 198.1 & 280.9 \\
$\quad$ Postinoculation $^{\mathrm{y}}$ & 24.9 & 70.4 & 211.3 \\
Contrasts & & & \\
$\quad$ Preinoculation $^{\mathrm{x}}$ & $74.5 \mathrm{a}$ & $227.4 \mathrm{a}$ & $342.3 \mathrm{a}$ \\
Postinoculation & $57.6 \mathrm{a}$ & $120.2 \mathrm{~b}$ & $294.3 \mathrm{a}$ \\
Water $^{\mathrm{w}}$ & $94.6 \mathrm{a}$ & $213.4 \mathrm{a}$ & $390.5 \mathrm{a}$ \\
0.5\% Clay & $37.5 \mathrm{~b}$ & $134.3 \mathrm{~b}$ & $246.1 \mathrm{~b}$ \\
\hline
\end{tabular}

${ }^{\mathrm{z}}$ All sprays contained $0.05 \%$ Tween 80 .

yPre-inoculation treatments were applied $24 \mathrm{~h}$ prior to pathogen inoculation and post-inoculation treatments were applied $24 \mathrm{~h}$ after pathogen inoculation. xProbability values were $P=0.0860$ for trial $1, P<$ 0.0001 for trial 2 and $P=0.0594$ for trial 3 .

"Probability values were $P<0.0001$ for trials 1,2 , and 3. Trials 1 and 3 data analysis was conducted using square root transformed data. 
Table 2: Effect of foliar application of clay and Tween 80 suspensions on the number of colonies of Sphaerotheca fuliginea forming on the leaves of cucumber plants.

\begin{tabular}{|c|c|c|c|}
\hline Foliar spray & Trial 1 & Trial 2 & Trial \\
\hline \multicolumn{4}{|l|}{ Water } \\
\hline Preinoculation $^{2}$ & 156 & 203.2 & 88.7 \\
\hline Postinoculation $^{z}$ & 170.3 & 200.9 & 89.7 \\
\hline \multicolumn{4}{|l|}{$0.1 \%$ Tween 80} \\
\hline Preinoculation $^{2}$ & 147.3 & 212.4 & 84.7 \\
\hline Postinoculation $^{z}$ & 94.3 & 158.8 & 54.2 \\
\hline \multicolumn{4}{|l|}{$\begin{array}{l}0.1 \% \text { Tween } 80 \\
\text { plus } 0.5 \% \text { clay }\end{array}$} \\
\hline Preinoculation ${ }^{\mathrm{z}}$ & 72.2 & 195.1 & 62. \\
\hline Postinoculation $^{2}$ & 32.6 & 76.7 & 29.7 \\
\hline \multicolumn{4}{|l|}{ Contrasts } \\
\hline Preinoculation $^{y}$ & $125.2 \mathrm{a}$ & $203.6 \mathrm{a}$ & 78. \\
\hline Postinoculation & $99.1 \mathrm{~b}$ & $145.5 \mathrm{~b}$ & 57. \\
\hline Water $^{\mathrm{x}}$ & $163.2 \mathrm{a}$ & $202.1 \mathrm{a}$ & \\
\hline $0.1 \%$ Tween 80 & $120.8 \mathrm{~b}$ & $185.6 \mathrm{a}$ & 69. \\
\hline $0.1 \%$ Tween $80^{y}$ & $120.8 \mathrm{a}$ & $185.6 \mathrm{a}$ & 69. \\
\hline $0.1 \%$ Tween 80 & & & \\
\hline plus $0.5 \%$ clay & $52.4 \mathrm{~b}$ & $135.9 \mathrm{~b}$ & 42. \\
\hline
\end{tabular}

${ }^{2}$ Preinoculation treatments were applied $24 \mathrm{~h}$ prior to pathogen inoculation and postinoculation treatments were applied $24 \mathrm{~h}$ after pathogen inoculation. 'Probability values were $P<0.0001$ for trials 1,2 , and 3. Data analysis was performed using square root-transformed data.

xProbability values were $P=0.0003$ for trial $1, P=$ 0.1577 for trial 2 , and $P<0.0002$ for trial 3. Data analysis was performed using square root transformed data.

titratable acidity from 16.1 to 17.4 , and soluble solids from $18.6 \%$ to $19.6 \%$ ) or berry weight (ranging from 116 to $123 \mathrm{~g}$ ).

Chancellor' experiment. Weather conditions were ideal for the development of powdery mildew on 'Chancellor' grapes in 1998, as indicated by the widespread distribution on plant parts. The high rate of clay (4\%) was as effective as myclobutanil in reducing cluster and foliage powdery mildew and was superior in reducing cane powdery mildew (Table 3 ). The lower rate of clay was very effective in reducing cane and cluster powdery mildew but was not as effective on foliage powdery mildew. The clay and myclobutanil treatments had no significant effect $(P>0.05)$ on grape juice quality ( $\mathrm{pH}$ ranged from 3.43 to 3.59 , titratable acidity from 11.4 to 12.4 , and soluble solids from $18.4 \%$ to $20.5 \%$ ) or berry weight (ranging from 118 to $145 \mathrm{~g}$ ).

\section{Discussion}

The clay dusting experiment with cucumber gave inconsistent effects on powdery mildew, which may reflect the difficulty of getting consistently good leaf coverage by dusting the clay onto small plants. The results of our spray experiments with cucumbers show a decline in powdery mildew colony numbers of between $30 \%$ and $65 \%$ by foliar applications of clay. These results are comparable to the results obtained by Marco et al. (1994), who sprayed a higher concentration of clay suspensions $(10 \%)$ to control powdery mildew on field-grown squash plants.

Treatments were sometimes affected by the timing of pathogen inoculation, with treat-

Table 3. Average percent surface covered by powdery mildew on 'Reisling' and 'Chancellor' grapes after treatment with clay or Nova (myclobutanil).

\begin{tabular}{|c|c|c|c|c|}
\hline \multirow[b]{2}{*}{ Treatment and rate } & \multirow{2}{*}{$\frac{\% \text { Powdery mildew in Reisling }}{\text { Foliage }}$} & \multicolumn{3}{|c|}{$\%$ Powdery mildew in Chancellor } \\
\hline & & Foliage & Clusters & Canes \\
\hline Nontreated & $93.2 \mathrm{a}^{\mathrm{z}}$ & $94.4 \mathrm{a}$ & $67.5 \mathrm{a}$ & $52.2 \mathrm{a}$ \\
\hline $2 \%$ clay & $77.4 \mathrm{bc}$ & $74.5 \mathrm{ab}$ & $0.0 \mathrm{~b}$ & $31.0 \mathrm{bc}$ \\
\hline $4 \%$ clay & $70.9 \mathrm{c}$ & $43.3 \mathrm{~b}$ & $12.5 \mathrm{~b}$ & $25.8 \mathrm{c}$ \\
\hline Nova $\left(7.5 \mathrm{~g} \cdot 100 \mathrm{~L}^{-1}\right)$ & $90.2 \mathrm{ab}$ & $41.1 \mathrm{~b}$ & $5.0 \mathrm{~b}$ & $45.2 \mathrm{ab}$ \\
\hline
\end{tabular}

${ }^{2}$ Means followed by the same letter do not differ significantly according to the Waller-Duncan $K$-ratio $t$ test ('Reisling' grapes) and the Duncan's multiple range test $(P=0.05)$ ('Chancellor' grapes) on arcsintransformed data.

ment application prior to pathogen inoculation resulting in significantly more colonies per leaf than postinoculation treatments. This likely reflects the negative effect of water sprays on powdery mildew fungi. Yarwood (1939) and Jarvis and Slingby (1977) demonstrated that sprays of water alone can reduce the severity of powdery mildew pathogens. Free water reduces the viability of powdery mildew conidia (some will undergo plasmolysis in water) and causes abnormal hyphal growth on leaf surfaces (Schnathorst, 1965; Yarwood, 1957). Water in the preinoculation sprays would evaporate before coming in contact with the fungal conidia or hyphae, reducing the total effectiveness of the sprays.

The addition of $0.1 \%$ Tween 80 also enhanced the ability of the foliar sprays to reduce the severity of S. fuliginea on cucumber leaves in two of three trials in the surfactant vs. clay experiments. Tween 20 added to water sprays has also been shown to reduce the number of colonies per leaf by $50 \%$ for $S$. fuliginea on cucumber (Reuveni et al. 1995) and for $E$. orontii (a powdery mildew pathogen) on tomato (Ehret et al., in preparation). Our results with Tween 80 showed significant decreases in colony numbers by $19 \%$ to $39 \%$.

As was the case in the cucumber experiments, the application of clay as a spray in water was effective in reducing foliar infection of both 'Reisling' and 'Chancellor' grapes. Even though each cultivar was tested only once and in a different year, the results were similar. The clay seems to have a very long lasting effect. For example, $4 \%$ clay performed better than myclobutanil in preventing powdery mildew from developing on foliage of 'Reisling' grapes almost 8 weeks after the final spray. Clay was also effective in protecting grape berries from infection, as shown in 'Chancellor' grapes that had $68 \%$ of untreated clusters infected compared with $12 \%$ or less for the clay treatments. The lack of infection on 'Reisling' berries may have been due to the fact that the mildew did not get started until late in the season, a time when the berries were resistant to infection.

Our results, and those of Marco et al. (1994), demonstrate that the foliar application of clay can reduce the severity of powdery mildew on different crops. Although the total number of host-pathogen systems that have been examined so far are small, the results of this work suggest that further studies are warranted. In particular, the commercial and economic feasibility of clay sprays should be assessed. Foliar applications of clay may be a useful disease control technique in situations where fungicides cannot be used or are undesirable.

\section{Literature Cited}

Bélanger, R.R., A.J. Dik, and J.G. Menzies. 1998. Powdery mildews: Recent advances toward integrated control, p. 89-109. In: G.J. Boland and L.D. Kuykendall (eds.). Plant-microbe interactions and biological control. Marcel Dekker, New York, N.Y.

British Columbia Ministry of Agriculture, Fisheries and Food. 1996. Greenhouse vegetable production guide for commercial growers. Victoria, B.C., Canada.

Ehret, D.L., B.J. Zebarth, J. Portree, and T. Garland. 1998. Clay addition to soilless media promotes growth and yield of greenhouse crops. HortScience 33:67-70.

Jarvis, W.R. and K. Slingby. 1977. The control of powdery mildew of greenhouse cucumber by water sprays and Ampelomyces quisqualis. Plant Dis. Reptr. 61:728-730.

Marco, S., O. Ziv, and R. Cohen. 1994. Suppression of powdery mildew in squash by applications of whitewash, clay and antitranspirant materials. Phytoparasitica 22:19-29.

Menzies, J.G. and B.H. MacNeill. 1986. Asexual recombination in Erysiphe graminis f. sp. tritici. Can. J. Plant Pathol. 8:400-404.

Pearson, R.C. 1988. Powdery mildew, p. 9-11. In: R.C. Pearson and A.C. Goheen (eds.). Compendium of grape diseases. APS Press, St. Paul, Minn.

Reeser, P., D.J. Hagedorn, and D.I. Rouse. 1983. Quantitative inoculations with Erysiphe pisi to assess variation of infection efficiency on peas. Phytopathology 73:1238-1240.

Reuveni, M., V. Agapov, and R. Reuveni. 1995. Suppression of cucumber powdery mildew (Sphaerotheca fuliginea) by foliar sprays of phosphate and potassium salts. Plant Pathol. 44:31-39.

Sall, M.A., B.L. Teviotdale, and S.D. Savage. 1981. Powdery mildew, p. 46-50. In: D.L. Flaherty, F.L. Jensen, A.N. Kasimatis, H. Kido, and W.J. Moller (eds.). Grape pest management. Publ. No. 4105, Univ. of California, Berkeley.

Schnathorst, W.C. 1965. Environmental relationships in the powdery mildews. Ann. Rev. Phytopathol. 3:343-366.

Sholberg, P.L. and L.C. Lashuk. 1998. Efficacy of Ironwood (Minerall) clay against powdery mildew and bunch rot and effect on grape quality in 1997. Pest Mgt. Res. Rpt. No. 66. Ottawa, Ont. p. $181-182$.

Sholberg, P.L. and L.C. Lashuk. 1999. Efficacy of glacial marine clay for control of powdery mildew on grapes, 1998. Biol. Cult. Tests 14:46.

Yarwood, C.E. 1939. Control of powdery mildews with a water spray. Phytopathology 29:288-290.

Yarwood, C.E. 1957. Powdery mildews. Bot. Rev. 23:235-293.

Ypema, H.L., M. Ypema, and W.D. Gubler. 1997. Sensitivity of Uncinula necator to benomyl, triadimefon, myclobutanil, and fenarimol in California. Plant Dis. 81:293-297. 